\title{
37. GEOLOGIC SYNTHESIS OF LEG 19 (DSDP) RESULTS; FAR NORTH PACIFIC, AND ALEUTIAN RIDGE, AND BERING SEA
}

\author{
David W. Scholl, U. S. Geological Survey, Office of Marine Geology, Menlo Park, California \\ Joe S. Creager, Department of Oceanography, University of Washington, Seattle, Washington ${ }^{1}$
}

\section{INTRODUCTION}

Elsewhere in this volume (see Parts III and IV), fairly detailed treatment of a variety of sedimentological, petrological, paleontological, and tectonic subjects have been presented. In this paper we synthesize these discussions and other available data in a general evaluation of the significant tectonic and sedimentological histories of the far north Pacific and the neighboring Bering Sea. This history extends back to the Late Cretaceous for the Pacific basin, but only to about the middle Miocene in the Bering Sea.

The stratigraphic columns of ten of the eleven Leg 19 drilling sites are shown on Figure 1. When arranged from right to left, in the order of drilling, the columns construct a generalized east-to-west geologic cross section of the North Pacific and adjacent Bering Sea.

\section{MAJOR TECTONIC RESULTS}

\section{Far North Pacific}

Although many thoughts have been expressed about the geologic history of the far north Pacific, and the Gulf of Alaska in particular, (Hurley, 1960; Hamilton, 1967; Pitman and Hayes, 1968; Grow and Atwater, 1970; Hays, 1970; Hayes and Pitman, 1970; Mammerickx, 1970; Opdyke and Foster, 1970; Peter and others, 1970; Jones, 1971; Jones and others, 1971; Jackson and others, 1972; and Hamilton, in press). The geologic information obtained at DSDP Sites 183 and 192 provides the only pre-Neogene control for this vast region (Figure 2). In the Gulf of Alaska, Neogene turbidite and pelagic units were also sampled during DSDP Leg 18 (von Huene, Kulm and others, 1971).

\section{Aleutian Abyssal Plain and Site 183}

Site 183 is located near Sea Map Channel (Figure 2; Grim, 1969; Grim and Naugler, 1969) close to the apex of the Aleutian Abyssal Plain. Deposition apparently began here in the late early Eocene with the accumulation of nannoplankton ooze over an alkali olivine basalt, which may have been implaced in association with the growth of relatively nearby Derickson or Sirius seamounts (see Natland, and Stewart and others, this volume). The population-rich but species-limited microflora of this chalk implies a high northern latitude, equivalent or perhaps slightly less than that of the site $\left(52.5^{\circ}\right.$; see Worsley, this volume). By late early Eocene time, sandy and silty turbidite layers began to accumulate over the plain. These terrigenous deposits contain a pollen assemblage that is dominated by conifers. In the Eocene, a time of warm

\footnotetext{
${ }^{1}$ Contribution No. 694 .
}

global climates, pine forests grew only in high latitudes, for example, the uplands flanking the Cook Inlet area of Alaska (see Wolfe, and Evitt, this volume, also Wolfe, Hopkins and Leopold, 1966; Wolfe and Hopkins, 1967; and Wolfe, 1971). Deposition of turbidites ceased sometime in the middle Oligocene, just prior to the accumulation of nannoplankton ooze. Again, the low speciation of the microflora in this ooze indicates a high-latitude depositional environment. Pelagic clay, barren of age-diagnostic fossils, accumulated over the chalk until about 12 to 13 m.y. ago, in the middle Miocene, when diatom ooze becan to accumulate. Although the introduction of volcanic ash began in the late Miocene and ice-rafted debris in the Pliocene, accumulation of diatomaceous debris has continued into the Holocene at a rate averaging about 16 $\mathrm{m} / \mathrm{m} . \mathrm{y}$.

\section{Relative Plate Motion}

Prior to the drilling of Site 183 two schools of thought prevailed about the age of the buried turbidite sequence of the Aleutian Abyssal Plain. One concluded that the sequence was most likely of pre-middle Tertiary age (Hamilton, 1967), an age derived by dividing the thickness of the overlying pelagic blanket by a typical sedimentation rate for pelagic debris. The other considered this "typical" rate as far too low and believed the plain to be of Miocene and younger age (Opdyke and Foster, 1970; Jones and others, 1971). The buried turbidite sequence of the Aleutian Abyssal Plain in the vicinity of Sea Map Channel is entirely of Paleogene age, confirming Hamilton's opinion.

Because Site 183 is located near the apex (northern or upslope corner) of the plain, the direction toward which several fossil deep-sea channels appear to converge, it is likely that turbidite deposition would have ceased here about the same time or perhaps later than elsewhere (i.e., southward) over the buried plain. However, some of the more easterly channels may have remained active longer (Figure 2), as suggested by Mammerickx (1970). The end of all turbidite sedimentation over the existing area of the Aleutian Abyssal Plain should probably not be placed later than the late Oligocene, or between 22 and 30 m.y. ago (Berggren, in press). Initiation of turbidite deposition would appear to be late early Eocene at the earliest, about 50 m.y. ago.

The existence of a fossil abyssal plain of Paleogene age immediately south of Alaska is important evidence bearing on the amount of relative motion that could have occurred between the Pacific and American plates during the Cenozoic Era (Pitman and Hayes, 1968; Atwater, 1970; Grow and Atwater, 1970; Hayes and Pitman, 1970.) As Hamilton (1967), Mammerickx (1970), Jones and others (1971) and Hamilton (in press) have emphasized, the 


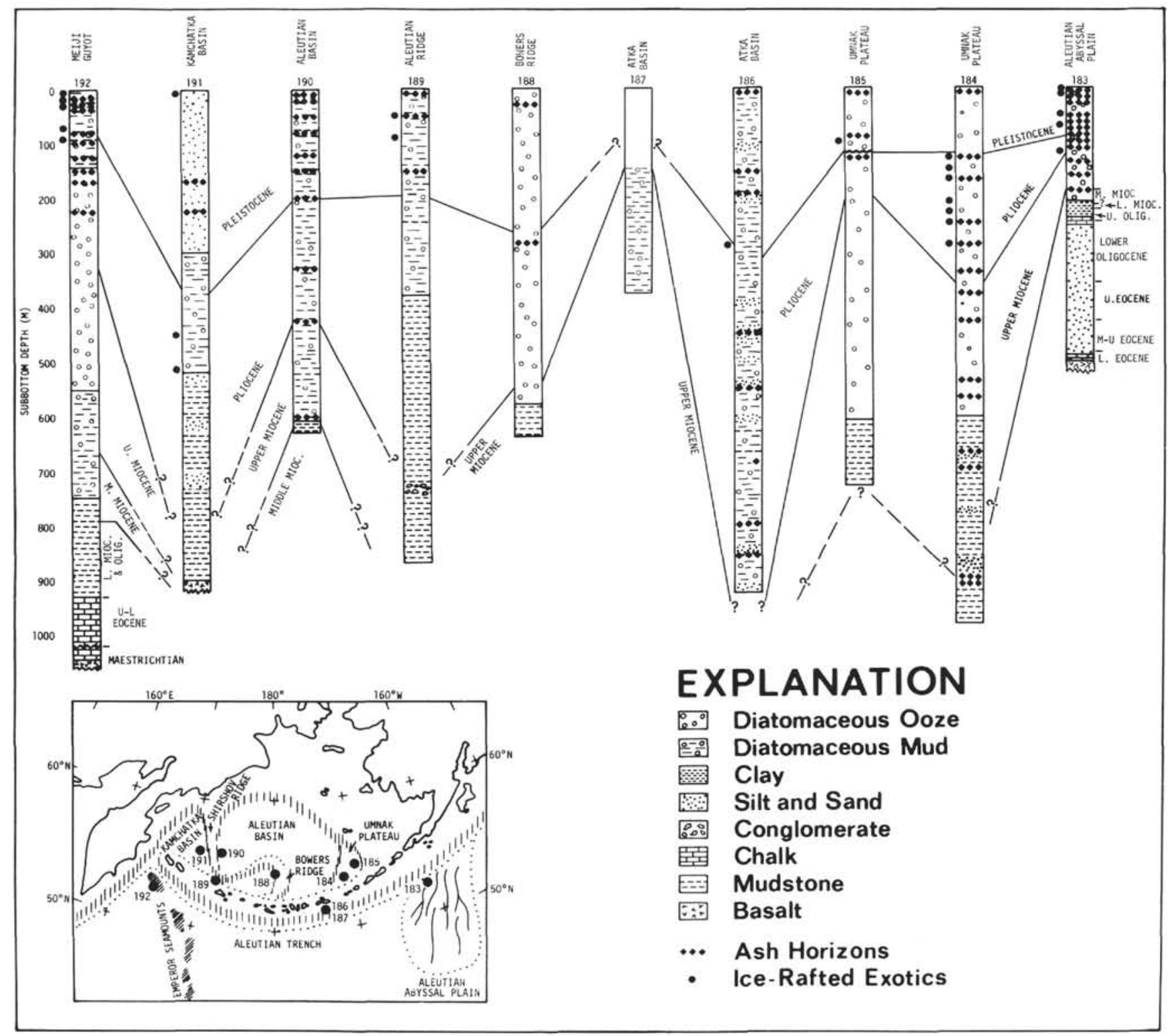

Figure 1. Stratigraphic columns of ten DSDP drilling sites, 183-192, far north Pacific and Bering Sea.

geomorphology and geometry of the terrigenous sedimentary bodies underlying the Aleutian Abyssal Plain are indicative of a northern or Alaskan source region, the Cook Inlet area being the apparently obvious drainage route (Figure 2). As workable models of relative motion between the Pacific and American plates (Atwater, 1970; and Grow and Atwater, 1970) allow for several thousand kilometers of relative motion during the Cenozoic, an Alaskan source terrain could be more apparent than real. Models of continuous plate motion during the Cenozoic imply that the turbidites of the Aleutian Abyssal Plain may have been deposited in the early Tertiary off the Washington or Oregon coast.

Although arguments to the contrary can be presented, (see below) the bulk of the findings at Site 183 appear to favor a model of limited, and therefore discontinuous, motion between the Pacific and American plates during the
Cenozoic. The evidence includes the following: (1) the mineralogy of the Eocene turbidites indicates a plutonic and metamorphic source terrain including blue amphiboles; (R.J. Stewart, personn. commun.), this is also true of the early Tertiary deposits of the Cook Inlet area of Alaska (Kirschner and Lyon, in press), (2) the turbidite sequence lies stratigraphically between early Tertiary chalk beds that are characterized by a population-rich but species-poor microflora, a factor indicating a latitude of deposition equivalent to that of Site 183 (see Worsley, this volume), and (3) the turbidite deposits contain a terrestrial microflora dominated by Pinaceae pollen, a circumstance that almost compels an Alaskan source area because rocks of equivalent age south of Alaska are characterized by subtropical or tropical floras (see Wolfe, this volume.)

When combined, the paleontologic findings at Site 183, and the geomorphic and geometric arguments of Hamilton 


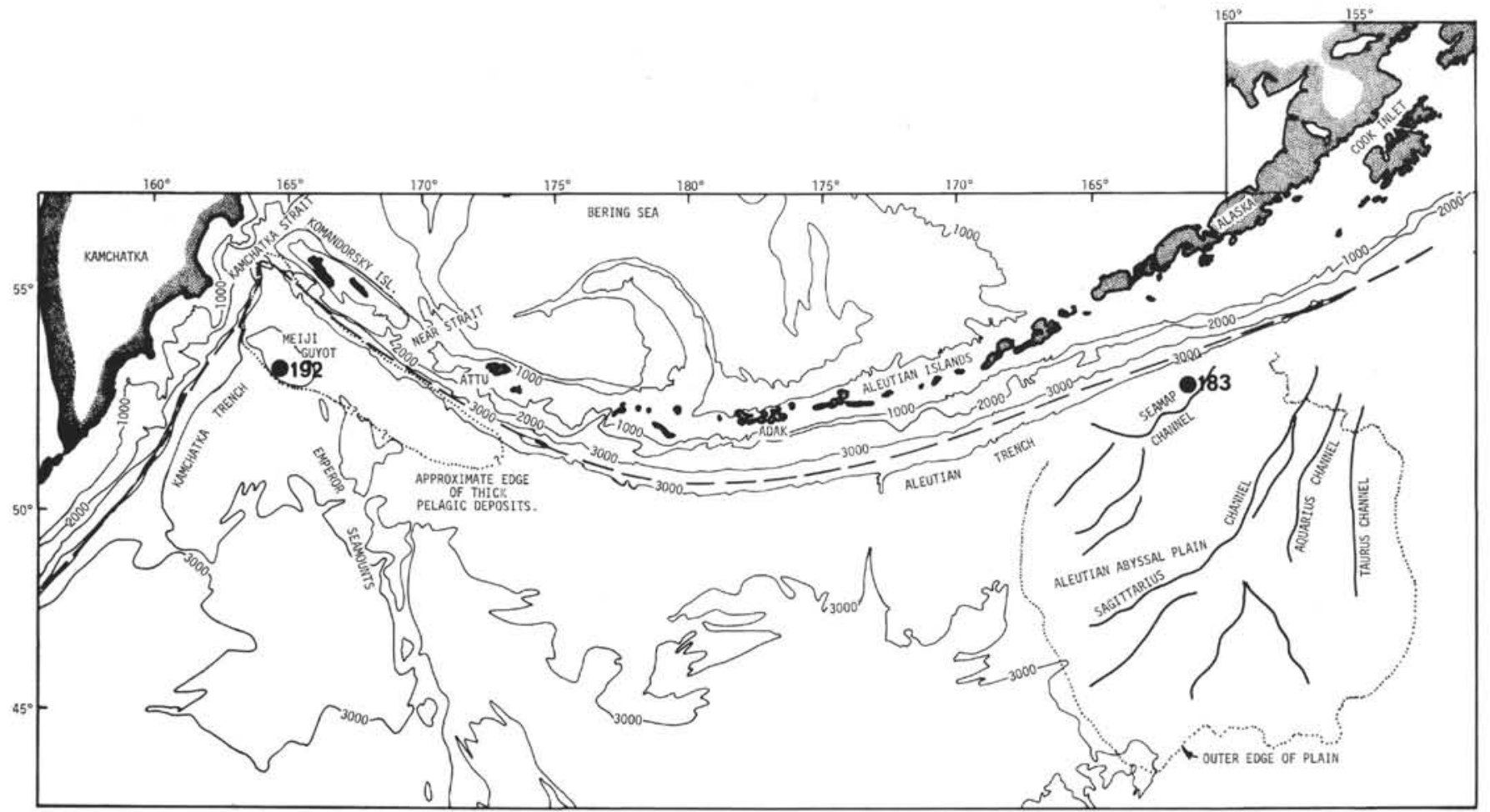

Figure 2. Location map for DSDP Sites 183 and 192, far north Pacific.

(1967), Mammerickx (1970) and Jones and others (1971), provide strong support for either little or no motion, an idea favored by Peter and others (1970), or for discontinuous plate motion, a model favored by Pitman and Hayes (1968) and Hayes and Pitman (1970). This conclusion has been reached independently by Hamilton (in press). None of the data are inconsistent with relative plate motions of about $500 \mathrm{~km}$ or perhaps slightly more during the Cenozoic the amount required to accommodate spreading adjacent to the Juan de Fuca Ridge and opening of the Gulf of California in late Cenozoic time. It is also noteworthy that motion along the San Andreas Fault in California is discontinuous, or nearly so, from the early Eocene to the Miocene (Dickinson and others, 1972). If displacement along the San Andreas Fault is a measure of relative motion between the two plates, then the observations of Dickinson and others are consistent (although they do not negate models of continuous motion) with the limited Cenozoic motion indicated by the Site 183 findings. The San Andreas data indicate a total Neogene displacement of about $300 \mathrm{~km}$. Also, Clague and Jarrard (in press) note that the Hawaiian hot spot (Jackson and others, 1972) shows little motion relative to the Pacific Plate between middle Eocene and early Miocene time (45-20 m.y.). If the hot spot is truly fixed, then little or no motion may have taken place between the Pacific and American plates during this same time. The data of Dickinson and others (1972) and the findings at Site 183 certainly suggest that this is the case.

Clague and Jarrard (in press) also stress that rapid Pacific Plate motion relative to the Hawaiian hot spot began in the early Miocene. This new motion may have initiated underthrusting of the Pacific Plate beneath Alaska and the formation of the Aleutian Trench, a circumstance that could explain the cessation of turbidite deposition on the Aleutian Abyssal Plain. However, the Site 183 data, and the measured dislocation across the San Andreas Fault during the last 20 m.y., can be interpreted to mean that less than about $500 \mathrm{~km}$ of underthrusting has taken place since the early Miocene. If this is true, then during the Neogene, the average rate of relative motion between the Pacific and the American plates may have been as little as $2 \mathrm{~cm} / \mathrm{y}$.

The rate of sediment consumption beneath an early Neogene Aleutian Trench would correspondingly not have been great, about $10 \mathrm{~km}^{3} / 10^{3} \mathrm{y}(1500-\mathrm{km}$ trench length $X$ $2 \times 10^{-5} \mathrm{~km} / \mathrm{y} \times 0.3 \mathrm{~km}$ sediment thickness $\left.\times 1000 \mathrm{y}\right)$, but nonetheless large enough to have interrupted the bulk of the sediment formerly delivered to the Aleutian Abyssal Plain. The roughly $300,000 \mathrm{~km}^{3}$ of turbidite debris (calculated from Site 183 data and the maps of Jones and others, 1971) beneath the plain accumulated at an average rate near $15 \mathrm{~km}^{3} / 10^{3} \mathrm{y}$.

However, the interruption by a "slow" (i.e., slow subduction rate) trench of a major sediment flow to the abyssal plain may have been only momentary. It seems very likely that local trench filling may have resulted and that supply to the abyssal plain to the south could have resumed, by overflow, within a few million years. It is reasonable to speculate, therefore, that cessation of turbidite deposition was principally related to either (1) a dramatic decrease in the volume of sediment carried to the Gulf of Alaska, or (2) the formation of additional and numerous (or large) upslope basins, besides the Aleutian trench, to trap terrigenous debris. For example, Kirschner 
and Lyon (in press) emphasize that a major drainage change took place in middle Miocene time. This change involved the shift of a paleo-Yukon River from draining to the Pacific via a path through Cook Inlet (Figure 2) to its present Bering Sea outlet. The cessation of turbidite deposition on the Aleutian Abyssal Plain occurred about 10 m.y. earlier, and may represent the first depositional "casualty" of the rising Alaskan Range and the restriction of the coastal region from interior drainages. Supporting this possibility is a major unconformity that separates Paleogene and Neogene deposits in the Cook Inlet area, which contains as much as 10,000 meters of Tertiary section. The unconformity separates the largely Neogene Kenai Formation, which probably includes some beds as old as Oligocene (Wolfe and others, 1966), from Chickaloon and equivalent units of Paleocene and Eocene age. Thus, in addition to the possibility of subduction in a newly formed Aleutian Trench, either the initial effects of a major drainage reorganization, or the blocking out of the thick $(7-8 \mathrm{~km})$ Neogene basin underlying the Cook Inlet area, or a combination of both, can be called upon in the late Oliogocene to restrict the outflow of terrigenous debris to the offshore Aleutian Abyssal Plain, located nearby in the Gulf of Alaska.

It should be pointed out that models of plate motion requiring as much as $1000-1500 \mathrm{~km}$ of relative motion are probably also consistent with the Site 183 data. Limiting motion to less than this amount allows the buried abyssal turbidites to remain in northern latitudes (generally about $50^{\circ} \mathrm{N}$ ) and also near an Alaskan source terrain, which need not have had a drainage via the Cook Inlet area. Even continuous motion models are possible, as an actively underthrust trench need not be crossed if the deep-sea channels nourishing the plain derived their sedimentary debris from southeastern Alaska, where the boundary condition between the Pacific and American plates was most likely a strike-slip (i.e., transform) fault (Atwater, 1970). The southeastern Alaskan source implies that the deep-sea channels feeding the plain were not only quite long, possibly exceeding $2500 \mathrm{~km}$, and passed via fracture zones south of the northward migrating Kula Ridge, but that the channels contributed sediment to a since vanished abyssal plain north of the ridge that may have been even larger than the extant Aleutian Abyssal Plain. Slow migration of the plain to the northwest may have cut it off from the contributing southeastern sources in late Oligocene time. Because the source area must have supplied a truly enormous amount of sediment to form the complex early Tertiary abyssal plain system, it is interesting to speculate that the termination of turbidite sedimentation might in part be related to a major drainage reorganization.

\section{Northern Emperors, Meiji Guyot and Site 192}

Site 192 is located on the summit of the northwesternmost seamount of the Emperor Seamounts (Figure 2). The seamount chain trends northwestward from the western end of the Hawaiian island-seamount chain (Jackson and others, 1972). Near its northern terminus, the Emperor chain loses much of its ruggedness owing to burial beneath as much as 2000 meters of topography-subduing pelagic deposits. Also near this end, the trend of the chain changes from north-northwest to northwest; Meiji Guyot, at a depth of 3000 meters, is a sediment-blanketed flat-topped seamount at the distal end of this trend.

At Meiji, a blanket of pelagic, hemipelagic, volcanic, and ice-rafted debris approximately 1044 meters thick covers alkali basalt. The pillowed alkalic flows, presumably represent terminal volcanism along the submerged upper flanks of the main volcanic mass approximately 72 m.y. ago, in early Maestrichtian (Late Cretaceous) time. Occurrence of nannofossils typically preserved in shallow-water deposits, and turbidite beds of eroded volcanic debris in middle and late Eocene deposits, imply that parts of Meiji Guyot were not completely submerged until about $38 \mathrm{~m} . \mathrm{y}$. ago. After this time, early Oligocene, a thick blanket of claystone and minor chalk formed above the wave-planed summit of Meiji Guyot. During Oligocene, early Miocene, and early middle Miocene time (38-12 m.y.), claystone accumulated at a rate near $9 \mathrm{~m} / \mathrm{m} . \mathrm{y}$. (Figure 3); when corrected for compaction effects, this rate increases to about twice this value (Table 1 ; see Lee, this volume). However, sometime in the middle Miocene, and possibly beginning in the early Miocene, the rate of clay accumulation increased to about $40 \mathrm{~m} / \mathrm{m} . \mathrm{y}$. (corrected; Figure 3). This rate continued until the late middle Miocene, approximately 12 m.y. ago, when the influx of diatomaceous debris (about 25\% of total sediment) increased sediment accumulation rates again, probably to values exceeding $60 \mathrm{~m} / \mathrm{m}$.y. (corrected; Table 1 ). In the late Miocene, 7-8 m.y. ago, and continuing into the early Pliocene, the infall of diatom frustules was sufficiently high for diatom ooze to accumulate at the astonishing rate of at least $100 \mathrm{~m} / \mathrm{m} . \mathrm{y}$. (Corrected). In late Pliocene and Pleistocene time, the influx of volcanic ash and ice-rafted debris did not offset a general decline in diatom productivity and sedimentation rates fell to about one-half this value. Opdyke and Foster (1970), using a chronology controlled by magnetic reversals, determined a late Pleistocene-Holocene sedimentation rate exceeding 21 $\mathrm{m} / \mathrm{m} . \mathrm{y}$. for the area of Meiji Guyot.

The dramatic change in sedimentation that took place over Meiji Guyot (Site 192) beginning in the late early Miocene is shown by the age vs. thickness curves in Figure 3. Fully 80 per cent of the sedimentary debris burying the summit of Meiji Goyot accumulated after this time (about 16 m.y. ago). Lee's (this volume) consolidation data indicate that the mudstone or claystone in this 80 per cent has compacted to at least half its original thickness. Diatom ooze, much of which contains from 15-40 per cent volcanic or terrigenous silt and clay, compacts much less. The in situ thickness of the ooze at Site 192 is probably only $20-25$ per cent less than a theoretical zero-overburden thickness. If rough compaction corrections are carried out for the 800 -meter-thick post-basal middle Miocene section at Site 192 , the section expands to nearly 1100 meters; about 60 per cent of this expanded section is volcanic or terrigenous mud and silt. Table 2 gives the rate of accumulation of this debris, and, for comparison, also that of the underlying sequence of Oligocene and lower Miocene claystone (Figure 1). The sharp increase in the rate of infall of non-biogenic detritus beginning sometime in the early Miocene is evident, and presumably implies a nearby continental or island arc source. The values listed on Table 2 also bring out the 
TABLE 1

Sedimentation Rates, Site 192, Meiji Guyot

\begin{tabular}{|c|c|c|c|c|}
\hline \multirow[b]{2}{*}{$\begin{array}{l}\text { Sediment } \\
\text { Type }\end{array}$} & \multirow[b]{2}{*}{$\begin{array}{l}\text { Thickness } \\
\text { (m) }\end{array}$} & \multirow[b]{2}{*}{ Age } & \multicolumn{2}{|c|}{$\begin{array}{l}\text { Sedimentation Rate } \\
(\mathrm{m} / \mathrm{m} . \mathrm{y} .)\end{array}$} \\
\hline & & & Compacted & $\begin{array}{l}\text { Uncompacted } \\
\text { (approx.) }\end{array}$ \\
\hline $\begin{array}{l}\text { Diatomaceous } \\
\text { silty clay and } \\
\text { volcanic ash }\end{array}$ & 140 & $\begin{array}{l}\text { U. Plio \& } \\
\text { Holo. } \\
\text { (3-0 m.y.) }\end{array}$ & 47 & $55-60$ \\
\hline Diatom ooze & 410 & $\begin{array}{l}\text { U. Mioc. \& } \\
\text { L. Plio. } \\
\text { (8-3 m.y.) }\end{array}$ & 82 & 100 \\
\hline $\begin{array}{l}\text { Diatom-rich } \\
\text { clay }\end{array}$ & 155 & $\begin{array}{l}\text { M. \& U. } \\
\text { Mioc. } \\
\text { (12-8 m.y.) }\end{array}$ & 39 & $55-60$ \\
\hline $\begin{array}{l}\text { Claystone, } \\
\text { minor chalk }\end{array}$ & 235 & $\begin{array}{l}\text { Olig., L. \& } \\
\text { M. Mioc. } \\
\text { (38-12 m.y.) }\end{array}$ & 9 & $18-20$ \\
\hline $\begin{array}{l}\text { Chalk and } \\
\text { claystone }\end{array}$ & 84 & $\begin{array}{l}\text { U. \& M. Eoc. } \\
\text { (49-38 m.y.) }\end{array}$ & $7-8$ & $12-15 ?$ \\
\hline Chalk, some & 20 & $\begin{array}{l}\text { M. \& L. } \\
\text { Maest. } \\
\text { (67-72 m.y.) }\end{array}$ & 4 & 6 \\
\hline
\end{tabular}

interesting fact that the estimated sedimentation rate of volcanic and terrigenous silt and clay has not greatly changed during the Neogene.

\section{Relative Plate Motion}

As emphasized above, Meiji Guyot has remained near a source of terrigenous and volcanic debris at least since the early Miocene, and perhaps since the end of the Oligocene. This source terrain could only have been either Kamchatka, immediately to the west, or the Aleutian Ridge, equally close but to the north.

Two greatly differing models of relative motion between the American-Asiatic and Pacific plates have been advanced in recent years by Pitman and Hayes (1968; see also Hayes and Pitman, 1970) and Atwater (1970; see also Grow and Atwater, 1970). The Pitman-Hayes model calls for little Tertiary motion but allows for a relative motion to the northwest beginning $34 \mathrm{~m}$.y. ago. One of Atwater's models prescribes more or less continuous Cenozoic motion in this direction. Insofar as Meiji, Guyot is concerned, the PitmanHayes (1968) model stipulates that the seamount has remained within a few hundred kilometers of its present position since earliest Tertiary time. The more mobile model of Atwater (1970), implies that Meiji Guyot traveled

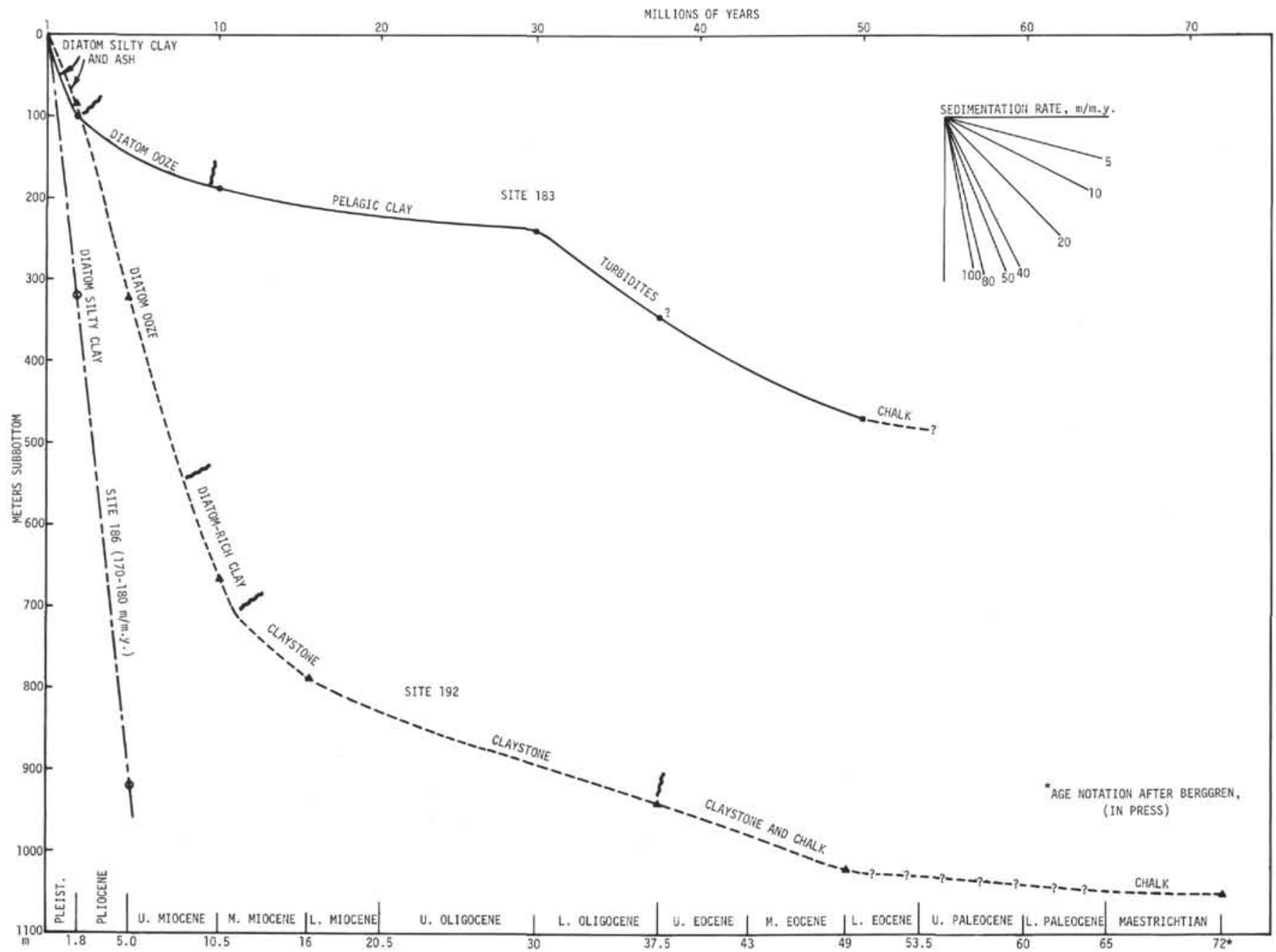

Figure 3. Diagram of age versus depth below sea floor of sedimentary deposits penetrated at DSDP Sites 183,186 and 192. 
TABLE 2

Approximate Sedimentation Rate for Volcanic and Terrigenous Silt and Clay ${ }^{\mathrm{a}}$

\begin{tabular}{lclc}
\hline \multicolumn{1}{c}{ Sediment Type } & $\begin{array}{c}\text { Thickness } \\
(\mathrm{m})\end{array}$ & \multicolumn{1}{c}{ Age } & $\begin{array}{c}\text { Sedimentation } \\
\text { Rate } \\
(\mathrm{m} / \mathrm{m} . \mathrm{y} .)\end{array}$ \\
\hline $\begin{array}{l}\text { Diatomaceous silty } \\
\text { clay and volcanic ash }\end{array}$ & 150 & $\begin{array}{l}\text { U. Plio. \& Holo. } \\
(3-0 \text { m.y. })\end{array}$ & 42 \\
$\begin{array}{l}\text { Diatom ooze } \\
\text { Diatom-rich clay }\end{array}$ & 150 & $\begin{array}{l}\text { U. Mioc. \& L. Plio. } \\
(8-3 \text { m.y. })\end{array}$ & 30 \\
$\begin{array}{l}\text { Claystone, minor } \\
\text { chalk }\end{array}$ & 170 & $\begin{array}{l}\text { M. \& Y. Mioc. } \\
(12-8 \text { m.y. })\end{array}$ & 41 \\
$\begin{array}{l}\text { Mlaystone, minor } \\
\text { chalk }\end{array}$ & 300 & $\begin{array}{l}\text { Olig. \& L. Mioc. } \\
(168-16 \text { m.y. }\end{array}$ & 42 \\
\hline
\end{tabular}

a Based on estimated zero-overburden thickness.

bUncompacted thickness of volcanic and terrigenous silt and clay.

to its present location from a position several thousand kilometers to the southeast. The Hawaiian hot spot concept (Jackson and others, 1972; Morgan, 1972; Morgan, in press; Clague and Jarrard, in press) further implies that Meiji Guyot may have formed near the present location of Hawaii, approximately $6000 \mathrm{~km}$ away along the line of Emperor-Hawaiian seamount trend.

Simply interpreted, the lithologic and biostratigraphic data collected at Site 192 can probably be harmonized most easily with a model of no motion (Peter and others, 1970 ) or with the Pitman-Hayes model of limited motion (i.e., several hundred kilometers or less). For example, the high rate of diatom productivity in surface waters beginning in late middle Miocene time (Table 1) is consistent with the existing location of Site 192 beneath the region of confluence of the south-flowing and cold Oyashio Current and the warmer waters of the northwest Pacific. Accordingly, high planktonic productivity would be expected here.

The sharp early middle Miocene (or sooner) increase in sedimentation (from 14 to $42 \mathrm{~m} / \mathrm{m} . \mathrm{y}$.) of pelagic clay over Meiji Guyot can be correlated with the mid-Tertiary orogeny that affected Kamchatka and the Kuril as well as the Aleutian Ridge. Much of coastal Kamchatka and the Koryak Mountains to the north was uplifted at this time and enormous quantities of debris were shifted to the east to be deposited in coastal basins, the western Bering Sea, and broad terracelike basins midway down the Kamchatka continental slope. Acoustic reflection records (Buffington, 1973 ) indicate that at least 3 to $4 \mathrm{~km}$ of Neogene deposits underlie these slope basins. Fine detrital debris bypassing them would be expected to accumulate over the adjacent floor of the northwestern Pacific. Site 192 is located here, and so is a thick, southeastward-trending plume-like mass of sediment thinning away from Kamchatka Strait, near the juncture of the Aleutian and Kamchatka trenches (Buffington, 1973).

The approximate boundaries of this plume, which lies mainly north of Meiji Guyot but parallel to the Aleutian Ridge, are delineated diagrammatically on Figure 2. The existence of this unusually thick mass of pelagic and hemipelagic debris is based on the data of Ewing and others (1968) and reflection profiles recorded aboard the Glomar
Challenger during Leg 19 and by Buffington (1973). The location and geometry of this plume; the fact that it thins from as much as 2000 meters in the vicinity of Kamchatka Strait, which separates the Aleutian Islands and the Asiatic continent (Figure 2), to about 500 meters south of Attu Island, Aleutians; and the fact that at least 50 per cent is composed of nonbiogenic detritus can be viewed as good evidence that a continental source area is required and that this area is Kamchatka and eastern Siberia. Although detritus and volcanic debris shed eastward from Siberia enters the Bering Sea, it is also swept into the Pacific by the Kamchatka Current of Lisitsyn (1969). Presumably, this suspended debris mixes with Pacific water and then drifts eastward south of the Komandorsky Islands to form the plume of pelagic and hemipelagic deposits found there. Some of the suspended sediment is most likely swept back into the Bering Sea via the Near Strait separating the Aleutian and Komandorsky Islands (Lisitsyn, 1969, p. 93), thereby in part accounting for the high rate of terrigenous sedimentation observed at Site 189 . It can be argued that Meiji Guyot is directly in the path of this sediment dispersal system, which definitely operated during the Pleistocene as shown by the distribution of ice-rafted debris studied by Conolly and Ewing (1970), and that it has remained so during at least the last 16 m.y., and possibly the last 20-25 m.y. A model of limited or even no relative plate motion between the Pacific and Asia is favored by a sediment dispersal mechanism requiring Kamchatka and eastern Siberia to be the principal source terrain.

The planktonic flora and fauna back through Oligocene time are subarctic in character and can also be interpreted to mean that Meiji Guyot was virtually stationary beneath the influence of the diverging and cold Oyashio (Kamchatka of Lisitsyn, 1969) Current. Upper Eocene elements indicate a somewhat warmer surface, but yet a cool-temperate condition. This circumstance fits well with the generally warmer climates that prevailed globally during the Eocene. Definitely more tropical elements are found in the Maestrichtian nannofossil chalks. However, the latitudinal width of tropical climates in the Late Cretaceous was very much broader than today and could have included the latitude of Site 192 (Worsley and Martini, 1970). Also, either the Aleutian Ridge did not exist in the Late Cretaceous or it was much smaller than its present size, which was probably reached in early Eocene time. Hence, expanded circulation of warm "Kuroshio" type water can be imagined in the late Mesozoic northwestern Pacific.

Paleontologic findings of Neogene age can also be interpreted in a manner that is consistent with a muchtravelled Meiji Guyot. For example, Maestrichtian and Paleogene temperate- and warm-water assemblages are easily harmonized with a model of large-scale Cenozoic migration, viz, several thousand kilometers. However, distant Neogene migration is not as easily reconciled with an accountable mechanism for the high rates of accumulation of pelagic clay beginning at least by early middle Miocene time (Tables 1 and 2). Considering the continuous platemotion scheme of Atwater (1970), Meiji Guyot would have been roughly $800-1000 \mathrm{~km}$ south of Adak Island, Aleutians at the beginning of the middle Miocene (Figure 2). During the Late Pleistocene and Holocene, pelagic debris (largely clay) accumulated in this area at a regional rate near 12 
m/m.y. (Opdyke and Foster, 1970). In comparison, early middle Miocene pelagic clay accumulated over the summit of Meiji Guyot at a rate more than three times this value.

Because the blanket of Miocene clay covering Meiji Guyot is part of a large plume-shaped body thickening back toward Kamchatka Strait, if a continental source for the clay is called for, then in the middle Miocene the developing plume was fully $2000-2500 \mathrm{~km}$ long. From the strait, the plume would have stretched $1500 \mathrm{~km}$ southeastward to Meiji Guyot, and then another $1000 \mathrm{~km}$ beyond to the distal end of the plume, which would have been in the approximate area of the present Aleutian Abyssal Plain. This pattern of sediment dispersal is difficult to accept; perhaps it is better to look to the relatively nearby Aleutian Ridge as the source terrain. However, as Buffington (1973) points out, the plume thins toward the ridge and the high erosion rate or ejection of pyroclastic debris required from the narrow ridge to form the Miocene mudstone are factors indicating the ridge cannot be the source terrane.

\section{General Conclusions}

Sedimentological and paleontological findings at Sites 183, Aleutian Abyssal Plain, and 192, Meiji Guyot, do not in themselves require explanations calling for plate motion relative to either the American-Asiatic Plate or, for that matter, the spin axis of the earth, since the Early Eocene (50 m.y. ago). However, Grow (this volume) has outlined a reasonable explanation for the findings of Sites 186 and 187, Atka Basin and outer ridge, that requires several hundred kilometers of plate underthrusting beneath the Aleutian Trench since the late Miocene. Marlow and others (in press; see also discussion below under heading "Uplift of Aleutian Ridge and Renewed Plate Motion, Sites 186, 187, and 189") and Scholl and others (in press) emphasize that the structural and magmatic history of the Aleutian Ridge is best understood in terms of a similar period of late Cenozoic underthrusting. Viewed as a whole, and accepting the concept that new oceanic crust is generated at oceanic ridges on a non-expanding earth (for an opposing view, see Peter and others, 1970), then the tectonic implications of the results obtained by deep-sea drilling in the far north Pacific during Leg 19 are perhaps most easily harmonized with the studies of Pitman and Hayes (1968), Atwater (1970), Francheteau and others (1970), Grow and Atwater (1970), Hayes and Pitman (1970), von Huene, Kulm and others (1971), Dickinson and others (1972), Jackson and others (1972), Morgan (1972), Clague and Jarrard (in press), Grow (in press), Larson and Chase (in press), Hamilton (in press), and Morgan (in press), if the following is true: (a) northward motion of the Pacific Plate relative to the spin axis and the American-Asiatic Plate in excess of about $500 \mathrm{~km}$ took place largely prior to Early Eocene ( 50 m.y. ago), and (b) during the last 20-25 m.y., motion of the American-Asiatic Plate relative to the Pacific Plate has been much less than that between it and the Hawaiian magma plume.

\section{Bering Sea and Aleutian Ridge}

The Bering Sea is a marginal oceanic lying behind a volcanically active island arc, the Aleutian Ridge (Shor,
1964; Ewing and others, 1965; Scholl and others, 1968; Stone, 1968; Scholl and others, in press). In plate tectonics, marginal or rear-arc basins of the western Pacific are generally considered to be geologically young extensional features related to the upwelling of basaltic magma behind a seaward-migrating arc-trench system (Karig, 1970, 1971; Matsuda and Uyeda, 1971; Packham and Falvey, 1971). They may also be segments of older oceanic crust isolated from the oceanic basin by the growth of the island arc (Shor, 1964; Scholl and others, in press). Because sedimentation of terrigenous and biogenic debris has been extremely rapid in the Bering Sea since at least the early Neogene, penetration to an igneous basement was possible at only one site, Site 191 in Kamchatka Basin (Figures 1, 4). Elsewhere, the bit rarely reached deposits older than early late Miocene, many kilometers above basement rock. However, important information on the late Neogene tectonic histories of Umnak Plateau and Bowers Ridge still was gathered.

\section{Kamchatka Basin and The Regional Emplacement of Basalt, Site 191}

Stewart and others (this volume) discuss in detail the basalt encountered at a subbottom depth near 900 meters at Site 191, Kamchatka Basin (Figure 4). The basalt is low in potash, has a low $\mathrm{Sr}^{87} / \mathrm{Sr}^{86}$ ratio, and is generally similar to "oceanic" basalts recovered from ridges and interarc basins. Based on three $\mathrm{K}-\mathrm{Ar}$ ages of plagioclase microlites, the basalt was emplaced about 29.6 m.y. ago, in the middle Oligocene. (Stewart et al., Table 3, this volume).

The density of the basalt, which in texture grades downward (over a 1.4-m-thick interval; the attempted core recovery was $14 \mathrm{~m}$ ) from variolitic to subdiabasic, is approximately $2.79 \mathrm{~g} / \mathrm{cc}$. In a nearby area, Ludwig and others (1971a) determined an in situ velocity (refraction method) of $6.64 \mathrm{~km} / \mathrm{sec}$, a value more than $1 \mathrm{~km} / \mathrm{sec}$ higher than the laboratory value reported by Christensen (this volume, Part III).

Seismic reflection and refraction data in the Kamchatka Basin indicate the basalt layer is regional in extent. A similar layer of igneous rock underlies a much thicker sequence of sediment in the neighboring Aleutian Basin (Shor, 1964; Gaynanov and others, 1968; Ludwig and others, 1971a; Scholl and others, in press). The presumed basalt under the Aleutian Basin at Site 190 (Figure 4) is probably also pre-Neogene.

Scholl and others (in press) stress that Kamchatka Basin is surrounded by structural alignments that appear to be as old as the earliest Tertiary. There is no compelling reason to suspect that emplacement of the basalt (at any time during the Cenozoic) was related to the formation of the Kamchatka Basin by a major drift of the Komandorsky segment of the Aleutian Ridge or of Shirshov Ridge, which borders the basin to the east. Instead, available data seem to imply that emplacement was related to modest pre-late Miocene extension that permitted ridgelike tholeiite to invade an existing basin and engulf older sedimentary debris of Paleogene and early Neogene age. Emplacement could have been later than the Miocene and may be continuing today. The high heatflow values from Kamchatka Basin (M. G. Langseth, pers. comm., Fornari et al., this volume) are 


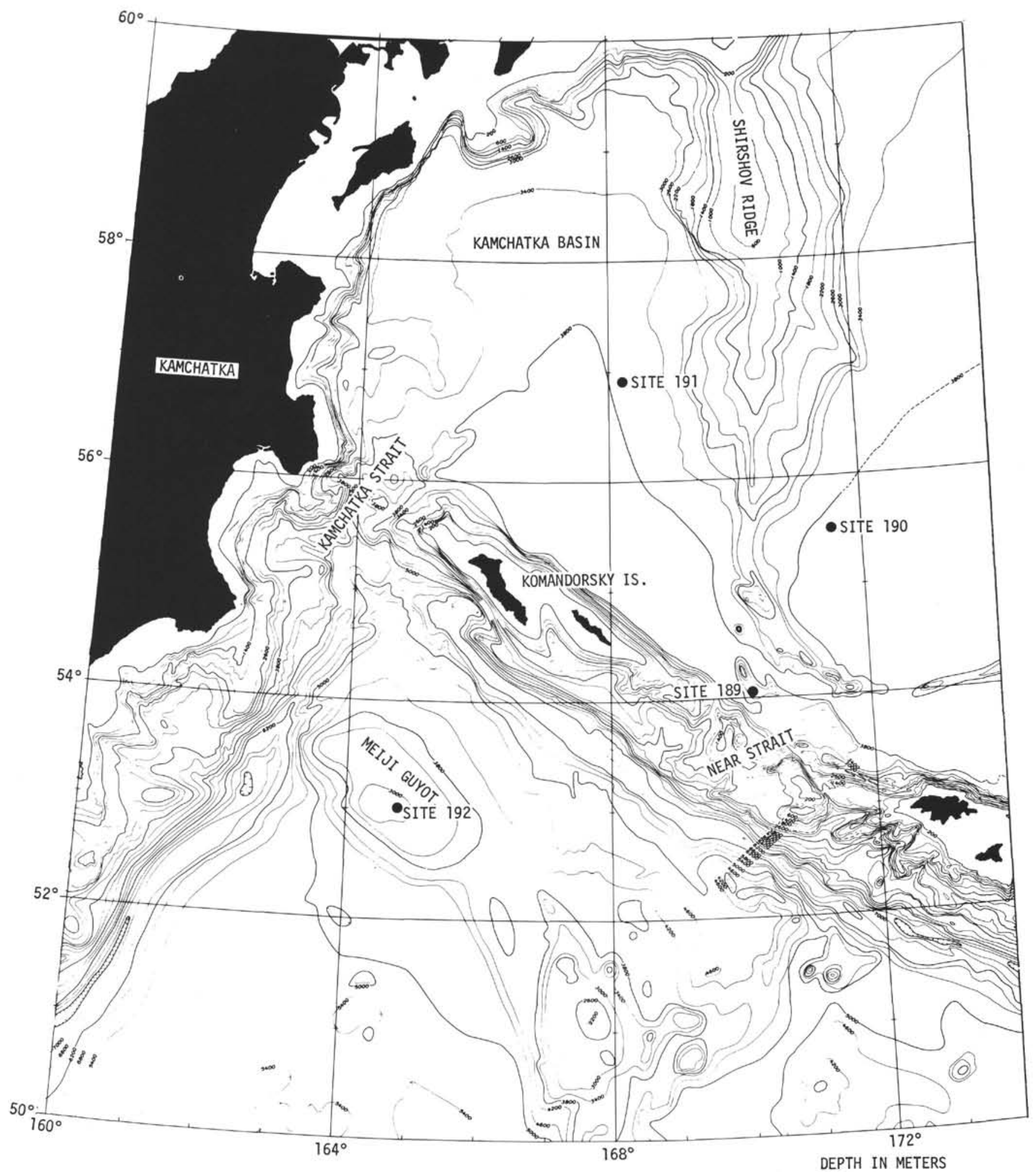

Figure 4. Location map of DSDP Sites 189, 190, and 191, western Bering Sea and Kamchatka Basin.

evidence supporting this possibility. However, basaltic intrusion is not associated with significant dilation of the basin as reflection records reveal its late Miocene and younger sedimentary blanket is unbroken by extensional rifting nor deformed by compressional folding around its periphery (Scholl and others, in press).

\section{Bowers Ridge, History of Subsidence and Uplift,} Site $\mathbf{1 8 8}$

Bowers Ridge (Figure 5) connects with the Aleutian Ridge near the center of the southward swing of this graceful arc. Looking like a ram's horn, Bowers Ridge 


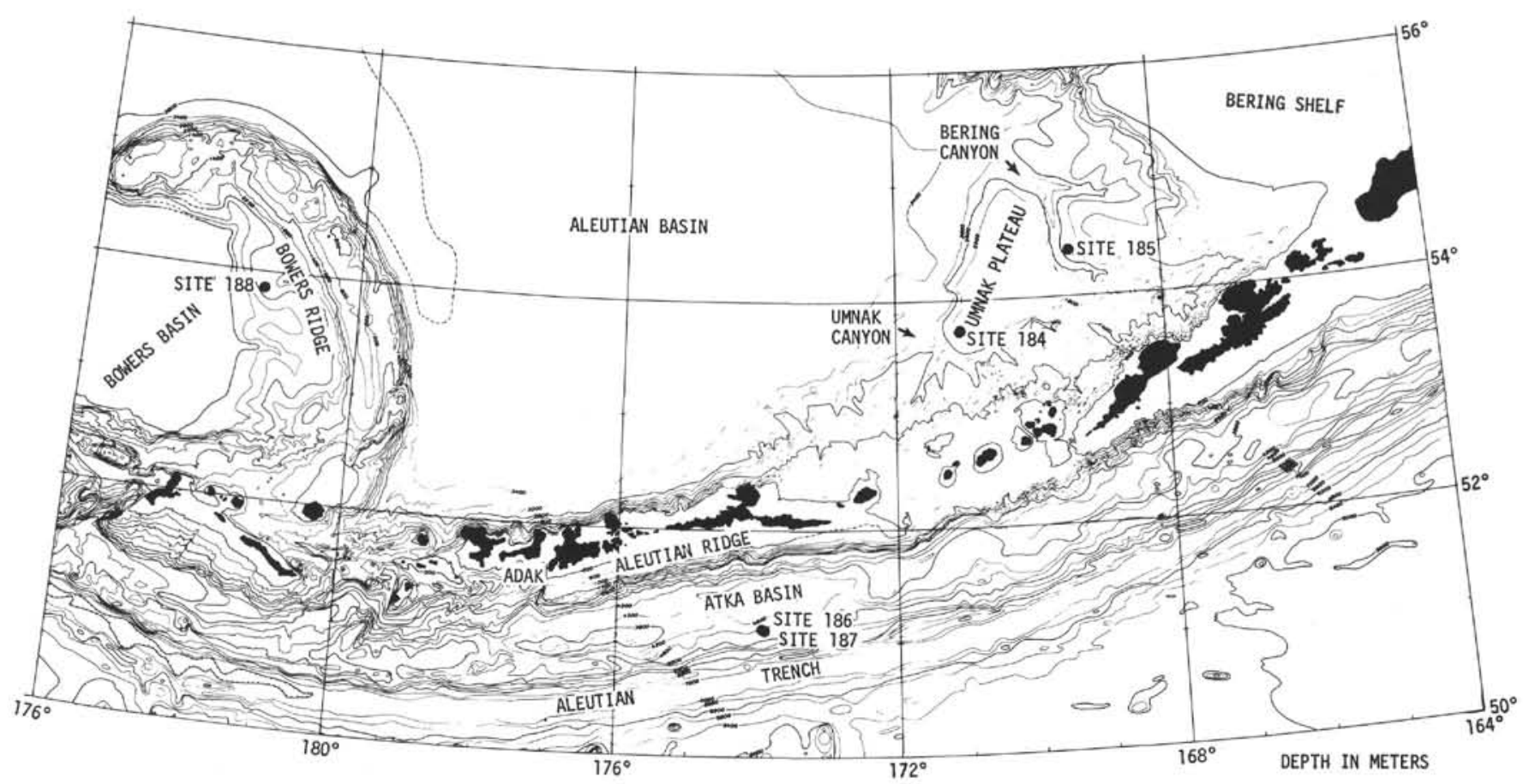

Figure 5. Location map of DSDP Sites 184, 185, 186, 187, and 188, Umnak Plateau, Atka Basin, and Bowers Ridge.

projects northward and then curls back to the west and nearly connects with Shirshov Ridge and the Aleutian Ridge in the vicinity of Near Strait (Figure 2). The top of Bowers Ridge is wave-planed in several areas (Scholl and others, in press). Because these denuded areas are submerged as deep as 1000 meters, there can be little doubt that subsidence of this magnitude has taken place. Although diatomaceous, the blanket of largely pelagic and hemipelagic sediment drilled and cored at Site 188 yielded few depth-diagnostic fossils. Thus no certain conclusion can be stated regarding the time of subsidence, or possible late Cenozoic uplift as speculated by Ewing and others (1965). However, the absence of numerous turbidite units, which might be expected had the largely diatomaceous sediment accumulated in the relatively small Bowers Basin, suggests that the sedimentary deposits draping the middle and lower western slopes of Bowers Ridge are not elevated basin deposits.

\section{Umnak Plateau, History of Subsidence and Uplift, Sites 184 and 185}

Like the webbing in a duck's foot, Umnak Plateau occupies the southeastern corner of the deep-water region of the Bering Sea (Figure 5). The plateau, except where cut by large submarine canyons, stretches between the converg. ing walls of the Aleutian Ridge to the south, and the continental margin of the Bering Sea to the north. The plateau is underlain by as much as 3000 meters of generally flat-lying deposits resting on an "acoustic basement" of unknown lithology; the section is locally pierced by diapir-like structures (Scholl and others, 1968; Scholl and Marlow, 1970).

Neritic diatoms occur in the Pliocene section at Site 184, near the Aleutian Ridge, but they are sparse at Site 185, closer to the Bering shelf (Figure 5). The presence of the neritic and sublittoral species between deposits containing chiefly marine assemblages can be viewed as evidence for cycles of uplift and subsidence. However, shelf lithofacies were never encountered and deep-water foraminifera occur with the shallow-water diatoms. The implication is that the neritic microflora is allochthonous and derived from the summit platform of the Aleutian Ridge. Lisitsyn's (1969) data show that the current flow reaching the area of Site 184 is from the Pacific and across the summit platform. It is especially interesting that the shallow-water assemblages are absent from beds of Pleistocene age, when sea level was periodically lowered in conjunction with continental glaciation. Their restriction to the Pliocene may mean that final bevelling of the summit platform took place at this time. The ridge was elevated in the late Tertiary, most likely the middle and late Miocene, after which much of the ridge top was deeply denuded and many of the between-island passages smoothed by wave planation.

Depth-diagnostic microfauna recovered from the sedimentary section beneath Site 184 indicate that the summit of the plateau has been at least as deep as it presently is, about 1900 meters, back through late late Miocene time. Perhaps this means that, in conjunction with sedimentation, the plateau has slowly subsided during the last 6-8 m.y.

\section{Uplift of the Aleutian Ridge and Renewed Plate Motion, Sites 186,187 , and 189}

Early in the geologic study of the Aleutian Ridge it was realized that a major hiatus separated early and late Cenozoic rocks. The unconformity was generally assigned to the mid-Tertiary (Gates and others, 1956). Subsequent studies by Anderson (1971; Marlow and others (in press), and Scholl and others (in press); placed the uplift in the 
Middle and Late Miocene, a judgement based largely on the $\mathrm{K} / \mathrm{Ar}$ age of plutonic bodies that invade rocks known to be as old as middle to late Eocene (Scholl and others, 1970b). Along the Aleutian Ridge, exposed rocks of late Miocene and early Pliocene age (3-10 m.y.) are not abundant, presumably marking a period of extensive erosion subsequent to uplift and plutonism and prior to the outbreak of andesitic volcanism that began to form the ridge's chain of late Cenozoic volcanoes about 2 m.y. ago (Bingham and Stone, 1971; Marlow and others, in press).

At Site 189 (Figure 4), located near the summit of an 800 -meter-high ridge lying just north of the base of the much larger Aleutian Ridge, pebbles of gabbro and sizegraded sedimentary breccia and sandstone bearing lithoclasts, were encountered at a subbottom depth of 740 meters. Although uncertainties remain, the probable age of the ridge-derived terrigenous breccia and sandstone is late Miocene, probably between 8 and 5 m.y. The terrigenous beds are inclined (dips up to 30 degrees) at angles too steep to be depositional slopes, hence deformation of the beds and possible uplift of the ridge must have taken place after or in latest Miocene time. The Site 189 ridge is on line with structural trends thought by Marlow and others (1970) to be of Pliocene to Holocene age; accordingly, deformation may have been continuous since the late Miocene.

At Site 189, and also at Site 186, Atka Basin (Figure 5), an enormous quantity of debris was swept from the Aleutian Ridge in Pliocene and Pleistocene time (Figures 3, 6). Uncorrected for compaction, the average sedimentation rate at the outer edge of the Atka Basin was equal to or greater than $180 \mathrm{~m} / \mathrm{m} . \mathrm{y}$. (Figure 3). Over the central part of the basin, the rate may have been twice this figure. Approximately 60 per cent of this sediment was supplied from the ridge as terrigenous or pyroclastic outfall, the bulk $(80 \%)$ of which is eroded detritus. Products of denudation alone account for a sedimentation rate near $85 \mathrm{~m} / \mathrm{m}$.y.; if corrected for compaction effects (see Lee, this volume), the rate becomes at least $100 \mathrm{~m} / \mathrm{m}$.y. Unfortunately, the rate of accumulation of terrigenous detritus for deposits of late Miocene age cannot be determined, as they were not encountered at Site 186. They were penetrated at nearby Site 187, but the deposits are much deformed and accumulation rates cannot be calculated. However, at Site 184 , also close to the ridge but north of it, late Miocene mudstone accumulated at a rate estimated at $70 \mathrm{~m} / \mathrm{m} . y$. , or about $140 \mathrm{~m} / \mathrm{m} . \mathrm{y}$. if compaction corrections are made. Thus, sustained rates of terrigenous sedimentation along the flanks of the Aleutian Ridge have in many areas been in excess of $100 \mathrm{~m} / \mathrm{m} . \mathrm{y}$. during at least the last 7-8 m.y.

The high rates of terrigenous sedimentation observed at Sites 189 and 186 (Figures 3, 6) probably attest to a more subaerially exposed Aleutian Ridge in late Miocene to Pleistocene time than exists now. At both of these sites, beds of late Miocene age are deformed and are typically recorded as an "acoustic basement" on seismic reflection records. A reasonable interpretation of these observations is that strong uplift in middle Miocene through early Pliocene time exposed much of the ridge top to subaerial erosion and also initiated widespread slumping and sliding of upper Miocene and older deposits that had accumulated as a thick (probably in excess of several kilometers) island-arc rise prism flanking the bases of the ridge. Part of this prism may now underlie the outer ridge of Atka Basin, penetrated at Site 187 (Figure 5; Grow, in press; also see Grow, this volume).

Deformation, uplift, and plutonism can be linked to a renewal of plate motion between the Pacific and the American-Asiatic plates. Plate motion apparently began about 20-25 m.y. ago after a quiescent period extending back to the middle Eocene (Clague and Jarrard, in press). Not unexpectedly, plutonism, attendant volcanism, and uplift did not occur until about 10 m.y. later. Perhaps the much later outbreak of late Pliocene and Pleistocene volcanism that constructed the existing chain of volcanoes can be related to the opening of the Gulf of California and a quickened pace of relative motion between the two plates (Marlow and others, in press; Scholl and others, in press).

\section{MAJOR SEDIMENTOLOGICAL RESULTS}

Geologically significant aspects of sedimentation were discussed in general terms in the previous section describing the major tectonic implications of the Leg 19 data. In this section we describe the sedimentological histories of the far north Pacific and the neighboring Bering Sea, arranging our discussion in chronological order. The stratigraphic and lithologic information gathered at each of the drilling sites (except 193, which was abandoned shortly after coring began because of a medical emergency) is shown by the stratigraphic columns on Figure 1 and indicated by annotation on the subbottom-depth vs. age diagrams of Figures 3 and 6 .

\section{Far North Pacific}

\section{Contact Mineralization}

At Sites 183, on the Aleutian Abyssal Plain, and 192, summit of Meiji Guyot (Figure 2), sediment just above and at the contact with alkali basalt (see Stewart and others, this volume) is enriched in $\mathrm{Fe}, \mathrm{Mn}$, and other metals. Aboard the Challenger it was initially speculated that thermal contact relationships were seen at Site 183, and that the basalt was intrusive into Late Cretaceous and Paleogene pelagic clay and chalk. However, detailed studies of the basal sediments by Natland (this volume) indicate that the basalt at each site is extrusive and that mineralization was subsequent to emplacement.

The Site 183 contact rock includes iron-rich claystone, clay-free goethite-bearing calcareous ironstone, and pyritebearing and strontium-rich aragonitic limestone. Aragonitic limestone and the clay-free ironstone $(16.2 \% \mathrm{Fe}$ and $2.8 \%$ $\mathrm{Mn}$ ) have not been reported previously in ferruginous basal sediment as commonly found in the Pacific. The mineralogy of the Site 183 deposits indicates they may be hot brine precipitates rather than pelagic sediment enriched by percolating hydrothermal exhalations (Natland, this volume). This opinion has profound implications for the distribution and formational environment of hot brines.

In contrast, at Meiji Guyot, altered alkali basalt is overlain by iron- and manganese-enriched claystone and chalk. Occurrence in the basalt of clay minerals, calcite and iron oxides, and iron and manganese oxides in cracks, seems to demonstrate that the mineralization of the overlying 


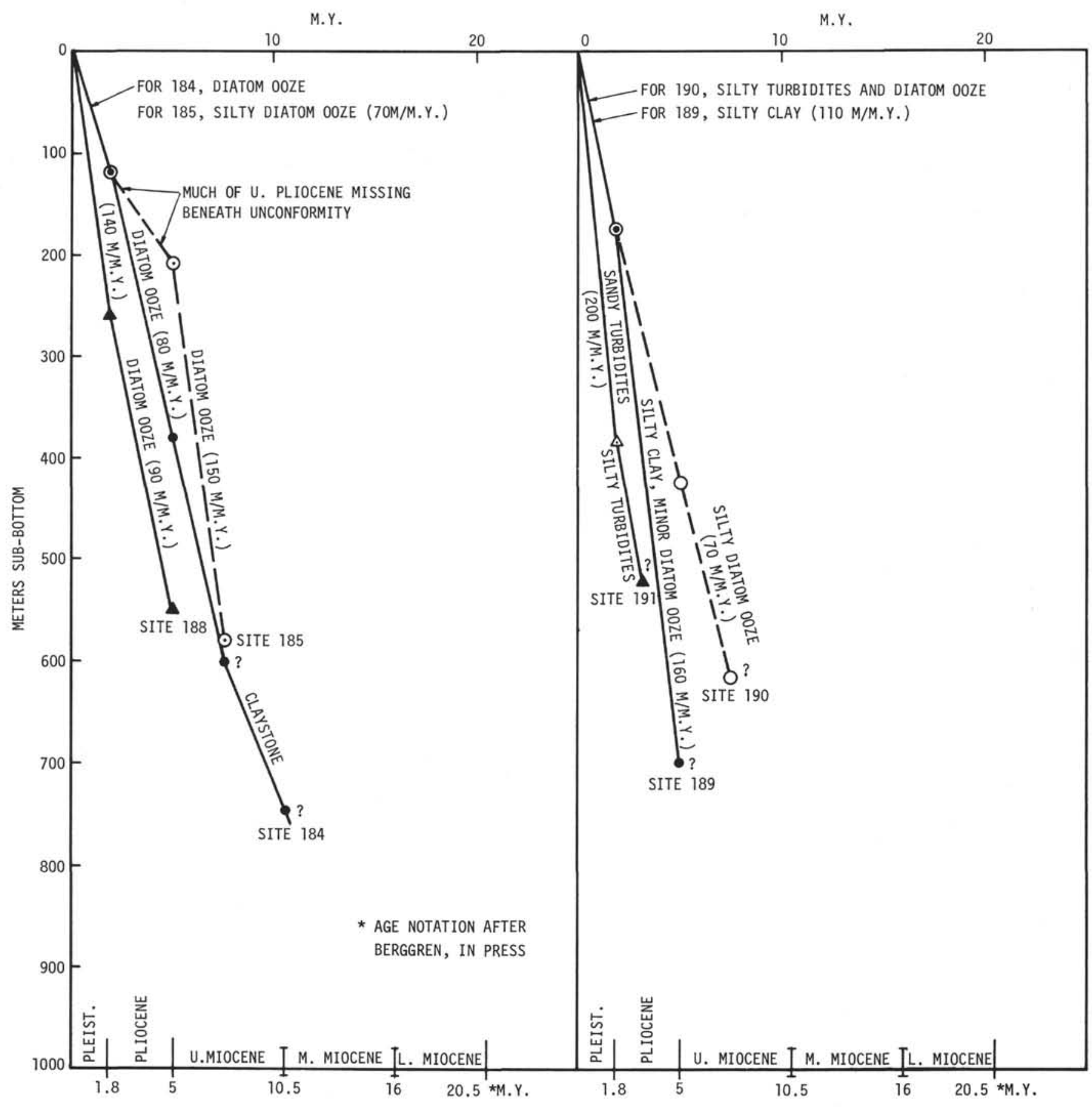

Figure 6. Diagram of age versus depth below sea floor of sedimentary deposits penetrated at DSDP Sites 184, 185, 188, 189, 190 , and 191 .

sediment took place at least in part diagenetically. The very special circumstance of contact mineralization at Meiji is that it took place at the summit of a subsiding seamount after final extrusion of alkali basalt. Thus basal ferruginous sediment also forms in environments other than those of oceanic ridges, where ferromanganese deposits are common (Boström and Peterson, 1966; see also Natland, this volume).

\section{The Missing Late Maestrichtian and Paleocene}

The oldest sediment reached at Site 183 was late Early Eocene (50 m.y. ago), yet the magnetic anomaly pattern in this area (Aleutian Abyssal Plain) suggests a basal age of early Paleocene (62 m.y. ago). Although there is always the possibility that a thin Paleocene section was inadvertantly not cored, the presence of highly mineralized basal sediment immediately above the basalt argues that Paleocene 
and lower Eocene beds are, in fact, virtually missing. This judgment hinges upon the age assigned to magnetic anomalies 24 and 25 (Heirtzler and others, 1968); not all are in agreement with these assignments (Meyerhoff and Meyerhoff, 1972).

Over the summit of Meiji Guyot, a profound unconformity was found between upper lower Eocene chalk and a similar chalk of middle Maestrichtian age. The missing sedimentary record extends from approximately 50 to 67 m.y., a 17 m.y. long hiatus. This hiatus in sedimentation has been recognized throughout most of the Pacific basin and apparently in part resulted from low surface water fertility during the transition time between the Mesozoic and the Cenozoic (Worsley, in press; see also Worsley and others, this volume).

\section{Eocene and Oligocene Turbidite Sedimentation}

The textural and mineralogical aspects of the lower Tertiary turbidites underlying the Aleutian Abyssal Plain have not been studied in detail. But limited information, as emphasized earlier, indicate the apparent source terrain for the sand, silt, and clay making up these deposits is Alaska, an idea originally proposed by Hurley (1960) and Hamilton (1967) and later emphasized by Mammerickx (1970) Jones and others (1971) and Hamilton (in press).

The estimated volume of terrigenous debris underlying the Plain is approximately $300,000 \mathrm{~km}^{3}$, a mass delivered in about 20 m.y. (between 50 and 25-30 m.y. ago). The average rate of delivery of debris to the plain was therefore about $15 \mathrm{~km}^{3} / 10^{3} \mathrm{y}$. This figure is equivalent to about 20 million metric tons of terrigenous detritus per year, a mass that is a substantial proportion of the total sediment yield of a large river. For example, the modern Yukon is estimated by Lisitsyn (1969) to discharge annually about 122 million metric tons to the Bering Sea. As speculated earlier, if a paleo-Yukon River draining through the Cook Inlet area (Kirschner and Lyons, in press) supplied the terrigenous debris to the Aleutian Abyssal Plain, presumably a large fraction of its total load was carried beyond the edge of the continent. A large submarine canyon of early Tertiary age may have been carved by the outflow of terrigenous debris across the continental margin. Scholl and others (1970a) have speculated that Zhemchug Canyon, one of the worlds largest known submarine canyons, was excavated into the continental slope of the Bering Sea by the outflow of Yukon detritus during episodes of glacially lowered sea level in the late Cenozoic.

\section{Maestrichtian and Cenozoic Chalk and the Carbonate Compensation Depth (CCD)}

Calcareous debris is not common in the Neogene part of sedimentary sections drilled in the far north Pacific. However, chalk of late Oligocene or early Miocene age was cored in the Gulf of Alaska at Site 178 (Leg 19, von Huene Kulm and others, (1971), and chalk of approximately middle Oligocene age ( 30 m.y. ago) was encountered at Site 183 just above the turbidite sequence (Figure 1). At this site, additional layers of chalk of late early Eocene age were found beneath the turbidite section. Atop the much shallower Meiji Guyot, significant amounts of chalk were encountered first in beds of early late Miocene age, but it becomes far more abundant below about 700 meters in beds of middle Miocene and older age (Figure 1). Chalk and calcareous units are the dominant lithology in Eocene through Lower Maestrichtian beds, except for the hiatus representing Late Maestrichtian and Paleocene time. Although chalks are not present in beds younger than late Miocene, calcareous debris is preserved in this section at Meiji Guyot $(3000 \mathrm{~m})$. This presumably means that the $\mathrm{CCD}$ has remained below this depth since the late Eocene. At Site 183, 4708 meters deep, the entire Neogene and upper Oligocene section is virtually devoid of calcareous microfossils, implying that the CCD remained about this depth during the last 30 m.y. However, major excursions to depths as great as 5000 meters occurred in the late and middle Oligocene and again in the late early Eocene. The CCD presumably rose to very high levels in the early Maestrichtian and Paleocene.

\section{Clay and Silt Sedimentation}

Considerable attention has already been given to the high rate of clay sedimentation atop Meiji Guyot probably beginning sometime in the late early Miocene (Figures 1, 3; Tables 1,2$)$. The preferred explanation for the increase involves the outfall of terrigenous and volcanic debris from an orogenically uplifted Kamchatka Peninsula and neighboring mountain ranges to the north. The data listed in Table 2 also demonstrate that the rate of accumulation of silt and clay atop Meiji Guyot and presumably throughout the entire area of the sediment plume extending southeastward from the confluence of the Aleutian and Kamchatka trenches, has remained generally the same since the early part of the middle Miocene. Any variation in overall sedimentation rate can be attributed to changes in diatom productivity and the influx of pyroclastic and ice-rafted debris.

It is interesting to note that at Site 183 , on the Aleutian Abyssal Plain, pelagic clay also accumulated in late Oligocene, early Miocene, and middle Miocene time. The clay is only 30 meters thick. The sedimentation rate (approximately corrected for compaction), averaged over this 17 m.y. time period, was a low 3 to $4 \mathrm{~m} / \mathrm{m}$.y. Because the clay is unfossiliferous, it is not known when it actually accumulated. However, accumulation of predominantly clayey sediment terminated rather abruptly approximately 13 m.y. ago, in the late middle Miocene, when diatom ooze began to form and the sedimentation rate increased to about $8 \mathrm{~m} / \mathrm{m}$.y. (corrected). About 25 per cent of the ooze is clay and silt-size detritus, corresponding to a partial sedimentation rate of about $2 \mathrm{~m} / \mathrm{m} . \mathrm{y}$. This probably signifies no change in the infall of pelagic clay and silt after diatom productivity rose. However, in the latter part of the Pliocene and in the Pleistocene, the influx of clay and silt over the plain increased markedly to values of about 20 and $60 \mathrm{~m} / \mathrm{m} . \mathrm{y}$. (corrected), respectively. The increase most probably reflects the strong Pliocene uplift of the coastal regions of southern and southwestern Alaska that formed most of its mountainous physiographic relief (Burk, 1965), and to the extensive glaciation that occurred here in late Cenozoic time. 


\section{Neogene Diatom Ooze}

Over Meiji Guyot, abundant and well-preserved diatoms appear first near the end of middle Miocene time. Extrapolations based on sedimentation rates indicate this occurred about 11.5 m.y. ago (Figure 3). Only vestiges of diatoms are preserved in immediately underlying claystone beds. At Site 183 , about $2500 \mathrm{~km}$ farther to the east, diatom ooze also appears abruptly in deposits of late middle Miocene age. Extrapolation of sedimentation rates gives an age of approximately 13.3 m.y., a value similar to that for the initial appearance of diatomaceous deposits at Meiji Guyot. At Site 183, the ooze rests on unfossiliferous pelagic clay. The slight age difference between the two sites, about 2 m.y., for the initial appearance of diatomaceous deposits is probably significant. The fact that vestiges of diatoms occur in the claystone at Site 192 implies that some of the diatomaceous deposits have been diagenetically altered to claystone or mudstone. This very important point is discussed more fully below in our description of the formation of the bottom-simulating reflector (BSR) found in the Bering Sea. In the Bering Sea, diatomaceous deposits do not appear until about 8 m.y. ago, in the late Miocene.

Figure 3 shows that the rate of accumulation of the diatom ooze atop Meiji Guyot in the late Miocene and early Pliocene was about $85 \mathrm{~m} / \mathrm{m}$.y., which corresponds to about $100 \mathrm{~m} / \mathrm{m} . \mathrm{y}$. when corrected for compaction effects (Table 2 ; see Lee, this volume). In comparison, at Site 183 on the Aleutian Abyssal Plain, diatom ooze accumulated at a rate of only $10 \mathrm{~m} / \mathrm{m} . \mathrm{y}$. (corrected). The high productivity of surface waters in the far northwest corner of the Pacific during the last $10 \mathrm{~m} . \mathrm{y}$. is confirmed by these figures.

The cause of the sudden increase in diatom productivity in the late middle Miocene surface waters cannot be determined in the far north Pacific because immediately underlying deposits are virtually devoid of environmentally diagnostic fossils. It is tempting to speculate that the increase resulted from an intensification of oceanic circulation and a consequent increase in the upwelling of nutrient-rich waters around the fringes of the far north Pacific. In this regard, Asano and others (1969) emphasize that, in Japan, middle Miocene planktonic populations characterized by warm-water species were replaced in late Miocene by cool-temperate and subarctic assemblages. Wolfe and Hopkins (1967) note a similar late Miocene cooling in the land flora of Alaska and western North America. A cooling trend beginning at the end of the middle Miocene is very evident in the antarctic and subantarctic regions (Margolis and Kennett, 1971). The cooling trend in the far north Pacific probably coincided with a shift in storm tracks and the boundaries between major wind systems, factors that might have triggered a virtually explosive output of diatom microflora. Uplift of the Aleutian Ridge in middle Miocene time which likely significantly restricted the flow of Pacific water into the Bering Sea, may have been a secondary cause for increased productivity in the far north Pacific.

\section{Late Cenozoic Volcanic Ash and Ice-rafted Debris (Including the Bering Sea)}

The explosive volcanic history of the North Pacific shows a great intensification of activity in the late Pliocene and Pleistocene, approximately 3 m.y. ago. At Site 183 , ashes do occur in beds as old as early late Miocene, signifying that the Neogene explosive history of the nearby Alaska Peninsula began at this time. This seems to agree with Burk's (1965, p. 107) description of the Cenozoic volcanism in this continental area. However, adjacent to the Aleutian Ridge and Kamchatka, the infall of abundant pyroclastic debris was delayed until the Pliocene. Bingham and Stone (1971) have dated some of the oldest rocks associated with the volcanoes of the Aleutian Ridge at about 2.0 m.y., which agrees nicely with the results reported in this volume.

The reason behind the intensification of explosive volcanism in the Pliocene is problematical, but it is tempting to link it with increased plate motion between North America and the Pacific. Presumably, such an increase would correlate with the rapid opening of the Gulf of California (Marlow and others, in press), which began approximately 2-3 m.y. earlier (Atwater, 1970).

Rafted exotics in the sediments of the North Pacific and the Bering Sea first appear in deposits of about middle Pliocene age (Figure 1). Although rafted particles of sand and silt may be present in older beds, pebble-size clasts occur rarely or not at all in deeper beds. Intensification of explosive volcanism and the appearance of presumably ice-rafted clasts occur at about the same time, 2-3 m.y. ago. The growth of the massive stratovolcanoes of Kamchatka and the Aleutian Islands, possibly attended by regional uplift, undoubtedly provided specific nursing grounds for alpine glaciers and possibly also increased annual precipitation as well as cloud cover. The coincidence of ice-rafted debris and volcanism in these high latitudes might therefore be the expected.

\section{Bering Sea}

Even a cursory glance at Figure 1 reveals that the bulk of the sedimentary section cored in the Bering Sea consists of diatom ooze, or a silty-clayey diatom ooze, and an underlying sequence of mudstone or claystone. As is true of the far north Pacific, volcanic ash and ice-rafted pebbles first appear in middle Pliocene deposits. Turbidites beneath the flat-floor of the Aleutian and Kamchatka basins first appear in abundance in the middle Pleistocene, although fine-grained deposits of distal turbidites occur in beds as old as late Pliocene. Many aspects of these sediments are discussed by Fullam and others (this volume). Probably the most puzzling aspect of the history of sedimentation in the Bering Sea is the contact between diatom ooze and the underlying mudstone, a contact that appears to be time transgressive and related to the formation of the bottomsimulating reflector.

\section{Diatom Ooze, Mudstone, and the Bottom-simulating Reflector}

Figure 7 is a reproduction of a seismic reflection record that traverses the southwestern corner of Umnak Plateau between Umnak Canyon and Site 184 (Figure 5). The upward-arched and prominent reflecting horizon that crosses coherent reflections from bedding planes is termed by us the bottom-simulating reflector, or simply the BSR. The BSR occurs within the sedimentary section draping the 


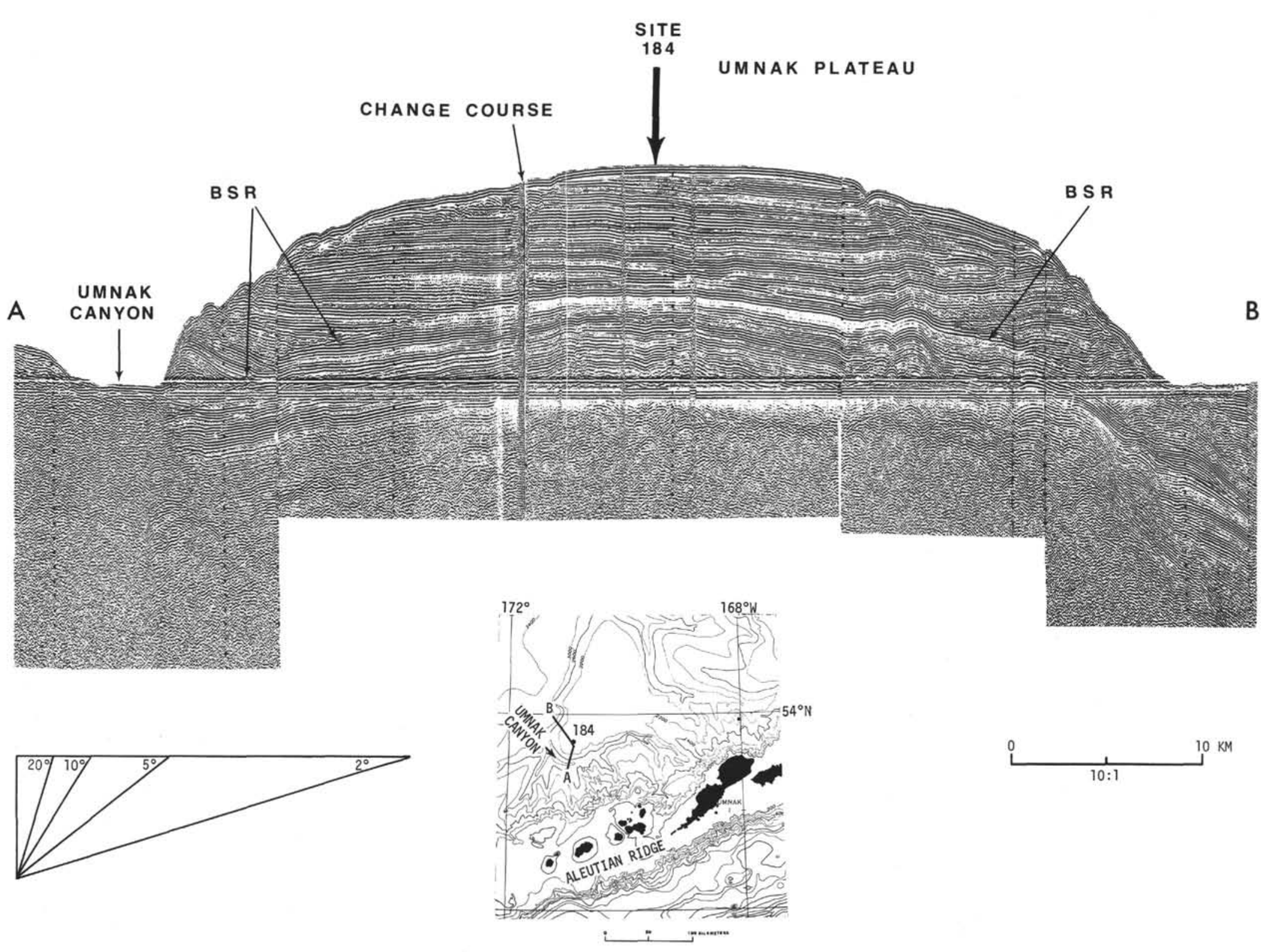

Figure 7. Seismic reflection profile through DSDP Site 184, Umnak Plateau, Bering Sea. 
flanking slope of the deep basin of the Bering Sea. It is difficult to recognize beneath flat-lying beds, but, because it characteristically changes dip in accordance with major changes in bathymetric slope, it is easily identified beneath a slope underlain by less steeply dipping beds. The BSR is not restricted to the Bering Sea; it has also been observed in the Pacific on seismic reflection records northeast of Meiji Guyot (Buffington, 1973), and it may be present in the Atlantic in the vicinity of Blake-Bahama Outer Ridge (Markl and others, 1970). Originally it was thought that the BSR was related to gas underlying a clathrated section (Stoll and others, 1971). However no evidence of gas hydrates was found in the Bering Sea cores.

in the Bering Sea, the BSR was reached and cored at three sites, 184, 185, and 188 (Figure 5). At each site the horizon was found to correspond to a contact between diatom ooze, or highly diatomaceous deposits and underlying mudstone or claystone nearly barren of siliceous microfossils. The bulk density and acoustic velocity of the claystone is much higher than that of the overlying diatom ooze, hence a prominent reflection event originates at the contact of the two units. Because the underlying claystone is poor in fossils, age control below the boundary is not good. However, the age down to the top of the boundary is fairly well known. Table 3 shows that it ranges from about 5.5 to 7 m.y. ago. The BSR is deepest where it is overlain by the oldest diatom ooze, and deepest where a thick section of slightly gaseous transitional sediment occurs. Also, the reflection profiles (see individual site reports, Part II) show that Sites 184 and 188 , where the BSR is nearest the seafloor and beneath the youngest deposits, are located on topographic and structural highs. Site 185 , on the other hand, is located midway down the slope of a spur separated from the main part of Umnak Plateau by Bering Canyon.

The relations noted on Table 3 seem to indicate that the BSR is a time transgressive horizon, although the ultimate lithologic transition from diatom ooze to claystone is everywhere the same. Because it seems unreasonable to suspect that diatom ooze, a pelagic deposit, would transgressively bury a gentle slope underlain by older deposits (Hamilton, 1967), the BSR would appear to represent some sort of migratory diagenetic boundary related to the dissolution of diatoms and the formation of claystone. We envision that in the early late Miocene, or possibly sooner, deposition of terrigenous clay slowly gave way to the accumulation of richer and richer diatom ooze. The transition zone was probably several hundred meters thick, or at least at thick $(155 \mathrm{~m})$ as the diatom-rich clay deposits of middle and upper Miocene age atop Meiji Guyot. This transition zone is still largely preserved at Site 185 , but at Sites 184 and 188 it has been completely obliterated by subsequent diagenetic effects.

Diagenetic alteration of diatom-rich clay to claystone is supported by the occurrence of vestigial remains of diatoms in the claystone, by beta-cristobalite in the transitional sediment, and by the interesting and revealing fact that the age of the base of the diatom ooze in the Bering Sea is 5-8 m.y. younger than that found in the North Pacific. Diagenetic loss of diatoms in the more richly terrigenous deposits of the Bering Sea could easily account for this age difference. Upward migration of the diagenetic boundary is
TABLE 3

Age, Depth, and Transitional Characteristics of BSR

\begin{tabular}{|c|c|c|c|}
\hline Site & $\begin{array}{l}\text { Depth } \\
\text { to } \\
\text { BSR } \\
\text { (m) }\end{array}$ & $\begin{array}{l}\text { Estimated Age } \\
\text { of Base of } \\
\text { Overlying } \\
\text { Diatom Ooze }\end{array}$ & Nature of Contact \\
\hline $\begin{array}{l}\text { 184, Umnak } \\
\text { Plateau }\end{array}$ & 600 & $\begin{array}{l}\text { Late Miocene } \\
(6-7 \text { m.y. })\end{array}$ & $\begin{array}{l}\text { Sharp, only a few meters of } \\
\text { transition-type deposits. }\end{array}$ \\
\hline $\begin{array}{l}\text { 185, Umnak } \\
\text { Plateau }\end{array}$ & 670 & $\begin{array}{l}\text { Late Miocene } \\
(7-8 \text { m.y.) }\end{array}$ & $\begin{array}{l}\text { Transitional across about } \\
100 \mathrm{~m} \text { of section, gas in } \\
\text { vicinity of contact zone. }\end{array}$ \\
\hline $\begin{array}{l}\text { 188, Bowers } \\
\text { Ridge }\end{array}$ & 580 & $\begin{array}{l}\text { Late late } \\
\text { Miocene } \\
(5-6 \text { m.y.) }\end{array}$ & $\begin{array}{l}\text { Sharp, only a few meters } \\
\text { of transitional type } \\
\text { sediment. }\end{array}$ \\
\hline
\end{tabular}

aAge determined by diatom zonation and extrapolation by sedimentation rates; see Koizumi, this volume, Part III.

apparently directly related to bottom topography. This would seem to indicate that the diagenetic boundary traces an isotherm. However, the boundary cannot move upward higher than the base of rather clean diatom ooze, i.e., where the clay and silt content falls below about $30-40$ per cent.

The hypothesis that the BSR is in someway related to the diagenetic alteration of clay-rich diatom ooze and diatom-rich clay to claystone, needs to be tested further. Detailed mineralogic studies of the transitional sediment is needed. Also, the apparent BSR beneath the Blake-Bahama Outer Ridge (Markl and others, 1970) should be tested for a possible diagenetic origin. Finally, cores are needed from lower down on the slopes flanking Umnak Plateau, where it is expected that the BSR is buried by the oldest diatom ooze and that a thick transitional zone is present.

\section{REFERENCES}

Anderson, R. E., 1971. Tectonic setting of Amchitka Island, Alaska. U. S. Geol. Survey Tech. Ltr. USGS474-75, Rev. 1, 46 p.

Asano, K., Ingle, J. C., and Takayanagi, Y., 1969. Neogene planktonic foraminiferal sequence in northeastern Japan. Proc. First Intl. Conf. Planktonic Microfossils, Geneva, 1967, Vol. 1, 14

Atwater, Tanya, 1970. Implications of plate tectonics for the Cenozoic tectonic evolution of western North America. Bull. Geol. Soc. Am. 81, 3513.

Berggren, W. A., in press. A Cenozoic time scale-some implications for regional geology and paleobiography. J. Foram. Res.

Bingham, D. K., and Stone, D. B., 1971. Paleosecular variation of the geomagnetic field in the Aleutian Islands, Alaska. Unpub. rept., Geophysical Institute, Univ. Alaska, College, Alaska.

Boström, K., and Peterson, M. N. A., 1966. Precipitates from hydrothermal exhalations of the East Pacific Rise. Econ. Geol. 61, 1258.

Buffington, E. C., 1973. The Aleutian-Kamchatka Trench convergence and investigations of lithospheric plate interaction in the light of modern geotectonic theories. Univ. South. Calif. dissert., Dept. of Geological Sciences (in prep.).

Burk, C. A., 1965. Geology of the Alaska Peninsula - island arc and continental margin (Part 1): Geol. Soc. Am., Memoir 99. 250 p. 
Clague, D. A., and Jarrard, R. D., in press. Tertiary Pacific Plate motion deduced from the Hawaiian-Emperor Chain with paleomagnetic, sedimentologic and tectonic consistancy tests. Bull. Geol. Soc. Am.

Conolly, J. R., and Ewing, M., 1970. Ice-rafted detritus in northwest Pacific deep-sea sediments. In Geological Investigations of the North Pacific. J. D. Hays (Ed.). Geol. Soc. Am., Memoir 126. 219.

Dickinson, W. R., Cowan, D. S., and Schweickert, R. A., 1972. Test of new global tectonics; a discussion. Bull. Am. Assoc. Petroleum Geologists. 56, 375 .

Ewing, J., Ewing, M., Aitken, T., and Ludwig, W. J., 1968. North Pacific sediment layers measured by seismic profiling. In The Crust and Upper Mantle of the Pacific Area. L. Knopoff, C. L. Drake, and P. J. Hart, (Ed.). Am. Geophys. Union Mono. 12. 522.

Ewing, M. Ludwig, W. J., and Ewing J., 1965. Oceanic structural history of the Bering Sea. J. Geophys. Res. 70, 4593.

Francheteau, J. C., Harrison, G. A., Sclater, J. G., and Richards, M. L., 1970. Magnetization of Pacific seamounts: A preliminary polar wandering curve for the northeast Pacific. J. Geophys. Res. 75, 2035.

Gates, O., Fraser, G. D., and Snyder, G. L., 1956. Preliminary report on the geology of the Aleutian Islands. Science. 119, 446.

Gaynanov, A. G., Kosminskaya, I. P., and Stroyev, P. A., 1968. Geophysical studies of the deep structures of the Bering Sea. Izvestiya, Physics of the Solid Earth, no. 3. 461.

Grim, P. J., 1969. Seamap deep-sea channel. ESSA Tech. Rept., ERL 93-Pol. 2, Seattle, Washington. 1.

Grim, P. J., and Naugler, F. P., 1969. Fossil deep-sea channel on the Aleutian Abyssal Plain. Science. 163, 383.

Grow, J. A., in press. Crustal and upper mantle structure of the central Aleutian Arc. Bull. Geol. Soc. Am.

Grow, J. A., and Atwater, T., 1970. Mid-Tertiary tectonic transition in the Aleutian Arc. Bull. Geol. Soc. Am. 81, 3715 .

Hamilton, E. L., 1967. Marine geology of abyssal plains in the Gulf of Alaska. J. Geophys. Res. 72, 4189.

, in press. Marine geology of the Aleutian Abyssal Plain. Marine geology.

Hayes, Dennis E. and Walter C. Pitmann III, 1970. Magnetic lineations in the North Pacific, In Geological Investigations of the North Pacific. J. D. Hays (Ed.). Geol. Soc. Am., Memoir 126. 291.

Hays, J. D., (Ed.), 1970. Geological Investigations of the North Pacific. Geol. Soc. Am., Memoir 126. 323 p.

Heirtzler, J. R., Dickson, G. O., Herron, E. M., Pitman, W. C. III and LePichon, X., 1968. Marine magnetic anomalies, geomagnetic field reversals, and motions of the ocean floor and continents: J. Geophys. Res. 73, 2119.

Hurley, R. J., 1960. The geomorphology of abyssal plains in the northeast Pacific Ocean. Ph.D. dissert., Univ. Calif., Scripps Inst. Ocean., La Jolla, Calif. 173 p.

Jackson, E. D., Silver, E. A., and Dalrymple, G. B., 1972. Hawaii-Emperor Chain and its relation to Cenozoic circumpacific tectonics. Bull. Geol. Soc. Am. 83, 601.

Jones, E. J. W., Ewing, J., and Truchan, M., 1971. Aleutian Plain sediments and lithospheric plate motion. J. Geophys. Res. 76, 8121 .

Jones, J. G., 1971. Aleutian enigma; a clue to transformation in time. Nature. 229, 400.
Karig, D. E., 1970. Ridge and basins of the TongaKermadec island arc system. J. Geophys. Res. 75, 239.

Karig, D. E., 1971. Origin and development of marginal basins in the western Pacific. J. Geophys. Res. 76, 2542.

Kirschner, E. D., and Lyons, C. A., in press. Stratigraphic and tectonic development of the Cook Inlet Petroleum Province. Proced. 2nd International Congress on Arctic Geology; Am. Assoc. Petrol. Geologists.

Larson, R. L., and Chase, C. G., in press. Late Mesozoic evolution of the western Pacific. Bull. Geol. Soc. Am.

Lisitsyn, A. P., 1969. Recent sedimentation in the Bering Sea. Nat. Sci. Foundation, Washington, D. C., Israel Program for Sci. Translations, 614 p.

Ludwig, W. J., Houtz, R. E., and Ewing M., 1971a. Sediment distribution in the Bering Sea; Bowers Ridge, Shirshov Ridge and enclosed basins. J. Geophys. Res. 76, 6367.

Ludwig, W. J., Murauchi, S., Den, N., Ewing, M., Hotta, H., Houtz, R. E., Yoshi, T., Asanuma, T., Hagiwara, K., Sato, T., and Ando, S., 1971b. Structure of Bowers Ridge, Bering Sea. J. Geophys. Res. 76, 6350.

Mammerickx, J., 1970. Morphology of the Aleutian Abyssal Plain. Bull Geol. Soc. Am. 81, 3457.

Margolis, S. V., and Kennett, J. P., 1971. Cenozoic paleoglacial history of Antarctica recorded in subantarctic deep-sea cores. Am. J. Sci. 271, 1.

Markl, R. G., Bryan, G. M., and Ewing, J. I., 1970. Structure of the Blake-Bahama Outer Ridge. J. Geophys. Res. 75, 4539.

Marlow, M. S., Scholl, D. W., Buffington, E. C., and Alpha, T. R., in press. Tectonic history of the central Aleutian Arc. Bull. Geol. Soc. Am.

Marlow, M. S., Scholl, D. W., Buffington, F. C., Boyce, R. E., Alpha, T. R., Smith, P. B., and Shipek, C. J., 1970. Boldir Depression - Late Tertiary graben on the Aleutian Ridge, Alaska. Mar. Geol. 8, 85.

Matsuda, T., and Uyeda, S., 1971. On the Pacific-type orogeny and its model-extension of the paired belt concept and possible origin of marginal seas. Tectonophysics. 11, 5 .

Meyerhoff, A. A., and Meyerhoff, J. A., 1972. "The new global tectonics": Age of linear magnetic anomalies of ocean basins. Bull. Am. Assoc. Petrol. Geologists. 56, 337.

Morgan, W. J., 1972. Deep mantle convection plumes and plate motions. Bull. Am. Assoc. Petrol. Geologists. 56, 203.

Morgan, W. J., in press. Plate motions and deep mantle convection. In $\mathrm{R}$. Shagan (Ed.). Hess memorial volume, Geol. Soc. Am. Memoir.

Opdyke, Neil D., and Foster, John H., 1970. Paleomagnetism of cores from the North Pacific. In Geological Investigations of the North Pacific. J. D. Hays (Ed.). Geol. Soc. Am., Memoir 126. 83.

Packham, G. H., and Falvey, D. A., 1971. An hypothesis for the formation of marginal seas in the western Pacific. Tectonophysics. 11, 79 .

Peter, G. D., Erickson, B. H., and Grim, P. J., 1970. Magnetic structure of the Aleutian Trench and northeast Pacific basin. In The Sea, Vol. 4. A. E. Maxwell (Ed.). London (Pergamon Press). Pt. 2, 191.

Pitman, W. C. III, and Hayes, D. E., 1968. Sea-floor spreading in the Gulf of Alaska. J. Geophys. Res. 73, 6571.

Scholl, D. W., Buffington, E. C., and Hopkins, D. M., 1968. Geologic history of the continental margin of North America in the Bering Sea. Mar. Geol. 6, 297. 
Scholl, D. W., Buffington, E. C., Hopkins, D. M., and Alpha, T. R., 1970a. The structure and origin of the large submarine canyons of the Bering Sea. Mar. Geol. 8, 187.

Scholl, D. W., Buffington, E. C., and Marlow, M. S., in press. Plate tectonics and the structural evolution of the Aleutian-Bering Sea region; solutions and complications. In Geology of the Bering Sea and Adjacent Regions. R. B. Forbes (Ed.). Geol. Soc. Am. Spec. Paper.

Scholl, D. W., Greene, H. G., and Marlow, M. S., 1970b. Eogene age of Adak "Paleozoic (?)" rocks, Aleutian Islands, Alaska. Geol. Soc. Am. Bull. 81, 3582.

Scholl, D. W., and Marlow, M. S., 1970. Diapirlike structures in the southeastern Bering Sea. Bull. Am. Assoc. Petrol. Geologists 54, 1644.

Shor, G. G., Jr., 1964. Structure of the Bering Sea and the Aleutian Ridge. Mar. Geol. 1, 213.

Stone, D. B., 1968. Geophysics in the Bering Sea and surrounding areas: A review. Tectonophysics. 6, 433.

Stoll, R. D., Ewing, J. and Bryan, G. M., 1971. Anomalous wave velocity in sediments containing gas hydrates. J. Geophys. Res. 76, 2090.
Von Huene, R., Kulm, L. D., and others, 1971. Deep Sea Drilling Project Leg 18. Geotimes. October. 12.

Wolfe, J. A., 1971, Tertiary climatic fluctuations and methods of analysis of Tertiary floras. Paleogeography, Paleoclimatology, Paleocology. 9, 27.

Wolfe, J. A., and Hopkins, D. M., 1967. Climatic changes recorded by Tertiary land floras in northwestern North America. In Tertiary Correlations and Climatic Changes in the Pacific. K. Hatai (Ed.). Tokyo, Japan, Univ. Tokyo, 11 th Pacific Sci. Congress. 67.

Wolfe, J. A., Hopkins, D. M., and Leopold, E. B., 1966, Tertiary stratigraphy and paleobotony of the Cook Inlet region, Alaska. U. S. Geol. Survey Prof. Paper 398-A. 29 p.

Worsley, T., and Martini, E., 1970. Late Maestrichtian nannoplankton provinces. Nature. 225 (5239), 1241.

Worsley, T., in press. Cretaceous-Tertiary boundary in the oceans. In History of the Ocean Basins. W. W. Hay (Ed.) Soc. Econ. Paleontologists and Mineralogist Spec. Paper, Tulsa, Okla. 